\title{
Body and testicular development and serum testosterone concentrations in Brahman males
}

\section{Desenvolvimento corpóreo, testicular e concentrações séricas de testosterona em machos Brahman}

\author{
Marcelo George Mungai Chacur ${ }^{1 *}$; Alex Arikawa Miyasaki²; Eunice Oba ${ }^{3}$; Camila \\ Dutra Souza ${ }^{4}$; Luis Roberto Almeida Gabriel Filho ${ }^{5}$
}

\begin{abstract}
The present study had the objective of evaluating the physical and testicular development, and the serum testosterone concentration of 8 to 18 months old male Brahman cattle on grazing weight gaining performance tests. Bovine cattle ( $\mathrm{n}=40)$, aged $259.76 \pm 26.15$ days and weighing $239.71 \pm 33,94 \mathrm{~kg}$ had the following characteristics evaluated every 56 days, corresponding to $8,10,12,14,16$, and 18 months of age (six different data collections): body weight (BW), scrotal circumference (SC), girth (G), height at the withers (WH), body length (BL), body mass index (BMI), right and left testicular length (RTL and LTL, respectively), right and left testicular height (RTH and LTH, respectively), average daily weight gain (ADG), testicular volume (TV), and serum testosterone (ST). Analysis of variance and Tukey's test at $5 \%$ probability were used. Correlations between variables were assessed using Pearson's method at $5 \%$ confidence. There was significant difference $(\mathrm{P}<0.05)$ from 12 months of age onwards for ADG and ST. There were differences $(\mathrm{P}<0.05)$ for: BW, SC, G, WH, BL, BMI, RTL, LTL, RTH, and TV from 14 months of age. There was a positive correlation between: ST x G $(\mathrm{r}=0.38$; $\mathrm{P}<0.01)$; ST x WH $(\mathrm{r}=0.38 ; \mathrm{P}<0.01)$; ST xRTH $(\mathrm{r}=0.23 ; \mathrm{P}<0.05)$; ST x LTH $(\mathrm{r}=0.21 ; \mathrm{P}<0.01)$; ST x TV $(\mathrm{r}=0.22 ; \mathrm{P}<$ $0.008)$; TV $\mathrm{x}$ weight $(\mathrm{r}=0.70 ; \mathrm{P}<0.01)$; TV x SC $(\mathrm{r}=0.90 ; \mathrm{P}<0.01)$; and TV x BMI $(\mathrm{r}=0.93 ; \mathrm{P}<0.01)$. A rapid increase in serum testosterone concentration occurred between 12 and 14 months of age, followed by rapid body and testicular growth. An elevation in testosterone levels is an indirect indicator that an acceleration inphysical and testicular growth is approaching. It is recommended to calculate both BMI and TV to follow cattle growth due to the high correlation between these variables.
\end{abstract}

Key words: Androgen. Male zebu. Body morphometry. Testes.

\section{Resumo}

Objetivou-se estudar o desenvolvimento corpóreo, testicular e a concentração sérica de testosterona dos 8 aos 18 meses de idade de machos Brahman em prova de ganho de peso à pasto. Os bovinos $(\mathrm{n}=40)$ com idade de $259,76 \pm 26,15$ dias e peso de $239,71 \pm 33,94 \mathrm{~kg}$, foram avaliados a cada 56 dias, em seis momentos, respectivamente, aos 8, 10, 12, 14, 16 e 18 meses de idade para: peso corpóreo (PC), circunferência escrotal $(\mathrm{CE})$, perímetro torácico $(\mathrm{PT})$, altura de cernelha $(\mathrm{HC})$, comprimento corporal (CC), índice de massa corpórea (IMC), comprimento testicular direito (CTD) e esquerdo (CTE), altura testicular direita (HTD) e esquerda (HTE), ganho médio diário de peso corpóreo (GMD), volume

${ }^{1}$ Prof. Dr., Universidade do Oeste Paulista, UNOESTE, Presidente Prudente SP, Brasil. E-mail: chacur@unoeste.br

2 Discente M.e, UNOESTE, Presidente Prudente, SP, Brasil. E-mail: alexmiyasaki@hotmail.com

3 Prof ${ }^{\text {a }} \mathrm{Dr}^{\mathrm{a}}$, Universidade Estadual Paulista, UNESP, Botucatu, SP, Brasil. E-mail: euniceoba@fmvz.unesp.br

${ }^{4}$ Discente de Doutorado, UNOESTE, Presidente Prudente, SP, Brasil. E-mail: camiladutrasouza@hotmail.com

${ }_{5}^{5}$ Prof. Dr., UNESP, Tupã, SP, Brasil. E-mail: gabrielfilho@tupa.unesp.br

* Author for correspondence

Received: Oct. 05, 2016 Approved: May 11, 2017 
testicular (VT) e concentração sérica de testosterona (TES).Utilizou-se a análise de variância, seguida por Tukey a $5 \%$. Para as correlações entre variáveis se empregou o método de Pearson a $5 \%$. Houve diferença $(\mathrm{P}<0,05)$ dos 12 meses de idade em diante para GMD e TES. Houve diferenças $(\mathrm{P}<0,05)$ para: PC, CE, PT, HC, CC, IMC, CTD, CTE, HTD e VT à partir de 14 meses de idade. Houve correlações positivas entre: TES x PT ( $r=0,38 ; \mathrm{P}<0,01)$; TES x HC $(\mathrm{r}=0,38 ; \mathrm{P}<0,01)$; TES x HTD $(\mathrm{r}=0,23 ; \mathrm{P}<0,05)$; TES x HTE $(\mathrm{r}=0,21 ; \mathrm{P}<0,01)$; TES x VT $(\mathrm{r}=0,22 ; \mathrm{P}<0,008)$ e do VT x peso $(\mathrm{r}=0,70 ; \mathrm{P}<0,01)$; VT $\mathrm{x}$ $\mathrm{CE}(\mathrm{r}=0,90 ; \mathrm{P}<0,01)$ e VT x IMC $(\mathrm{r}=0,93 ; \mathrm{P}<0,01)$. A elevação rápida da concentração sérica de testosterona ocorreu entre 12 e 14 meses de idade. Houve rápido crescimento corpóreo e dos testículos após a elevação significativa de testosterona. A elevação da testosterona, de forma indireta, indica a proximidade da aceleração do crescimento corpóreo e testicular. Recomenda-se calcular o índice de massa corpórea e o volume testicular para acompanhar o crescimento dos bovinos, devido à alta correlação entre essas variáveis.

Palavras-chave: Andrógeno. Macho zebu. Morfometria corpórea. Testículo.

\section{Introduction}

The rapid physical development and acceleration of weight gain during the puberty of male specimens of beef cattle breeds stems from the increase in testosterone (REDDY et al., 2014). Zebu beef cattle breeds exhibit greater adaptability to tropical climates, as their relative testosterone decrease is smaller than that of European breeds during the summer (QUEZADA-CASASOLA et al., 2016). The study of puberty in young zebus is of great importance, due to selection of sexually precocious (i.e. below the average herd age) future breeders (KUMAR et al., 2016). In Bos indicus, puberty usually occurs between the ages of 16 and 18 months (WOLF et al., 1965; LUNSTRA et al., 1978), but these males are seldom used for breeding purposes before the age of 2 (CHENOWETH et al., 1996; VALE FILHO et al., 1997). Variables such as age, weight, and scrotal circumference were equally important in the estimation of sexual maturity in male Bos indicus (BRITO et al., 2004).

The study of bovine physical development involves serial data collection of body and testes biometrics associated with hormonal concentrations (BERGMANN, 1999). The male reproductive organs develop rapidly during puberty in cattle (FRENEAU et al., 2006). Physical development studies of zebus mainly evaluate body weight and average weight gain (LÔBO et al., 2006; PACHECO et al., 2008).
According to Bergmann (1999), the testicular volume (TV) is one of the important variables when studying reproductive performance of male cattle. Neves et al. (2011) suggested measuring the scrotal circumference in beef cattle from weaning as a way to assist the selection of future breeders. Bergmann (1999) reported that testes grow rapidly during bovine puberty due to the significant increase in serum testosterone concentration.

The importance of the present study on prepubescent and pubescent male Brahman cattle stems from the need to expand knowledge inherent to this race's puberty, as the demand for natural breeding bulls in extensive farming systemin Brazil increases, from the transfer to females returning to estrus after hormonal treatment for artificial insemination in fixed time, and from the need to select sexually precocious young bulls for semen freezing purposes. Many beef cattle breeders still select animals for natural breeding by measuring scrotal circumference and weight gain, without knowledge of variables related to body biometrics, reproductive tract, and testosterone concentration that add helpful information in the choice of these males for breeding. In Brazil, the study of body biometrics, the reproductive system, and the serum concentration of testosterone from weaning to the age of one year old in the Brahman breed is still underdeveloped. The present study had the objective of studying the physical and testicular development, 
and the serum testosterone concentration of 8 to 18 months old Brahman males on grazing weight gaining performance tests, to assist in the selection of young bulls.

\section{Materials and Methods}

The research was approved by the Ethics and Animal Use Research Committee of the University of Western São Paulo, under Protocol 1634.

\section{Animals, location, and experimental period}

Male Brahman cattle $(n=40)$ with a mean age of $259.76 \pm 26.15$ days and body weight of $239.71 \pm 33.94$ $\mathrm{kg}$ were evaluated simultaneously during a collective grazing weight gaining performance (WGP) tests, maintained with Brachiaria brizantha, mineral mixture and water ad libitum (Capacity 0.8-1.0 $\mathrm{AUha}^{-1}$ ). The WGP was held on a rural property belonging to the municipality of Uberaba-MG, latitude $19^{\circ} 44^{\prime} 52^{\prime \prime} \mathrm{S}$, longitude $47^{\circ} 55^{\prime}$ '55'W, altitude of $823 \mathrm{~m}$, with high altitude tropical climate, between the months of June and April, for a total of 294 days.

\section{Data collection during the evaluation period}

Animals $(n=40)$ who participated in the collective grazing weight gaining performance (WGP) test were evaluated for 294 days, divided into 70 days of adaptation and 224 days of WGP. Data was collected in six occasions $(1,2,3,4$, 5 , and 6 ) at the ages of $8,10,12,14,16$ and 18 months, separated by intervals of 56 days. Data was collected upon animal weighing, according to the regulations of the Brazilian Association of Zebu Breeders (JOSAHKIAN et al., 2003) for grazing weight gaining performance tests (WGP).

\section{Physical and reproductive tract morphometry}

Cattle $(n=40)$ were contained in a cattle crush (mod. Tronco Brete VF Premium, Valfran ${ }^{\circledR}$,
Brazil), weighed on a digital scale (mod. Indicador VF Plus, Valfran ${ }^{\circledR}$, Brazil), and measured for the following variables: scrotal circumference $\mathrm{SC}(\mathrm{cm})$ and girth $\mathrm{G}(\mathrm{m})$, measured with a graduated metric tape;height at the withers WH (m) and body length BL (m), measured with a hypsometer (mod. two bar rod, Walmur ${ }^{\circledR}$, Brazil). The body mass index (BMI) was calculated with the equation: $\mathrm{BMI}=$ body weight $(\mathrm{kg}) /$ height at the withers ${ }^{2}(\mathrm{~m})$. The right and left testicular length (RTL and LTL, respectively) were measured in the dorso-ventral axis, and the right and left testicular height (RTH and $\mathrm{LTH}$, respectively) in the cranio-caudal axis with a caliper (Mitutoyo ${ }^{\circledR}$, Japan). The average daily weight gain (ADG) was calculated with the equation: $\mathrm{ADG}=$ body weight $(\mathrm{kg}) / \mathrm{age}$ (days). The testicular volume (TV) was obtained through the equation: $\mathrm{TV}=0.0396 \mathrm{x}(\mathrm{RTL}+\mathrm{LTL}) / 2 \mathrm{x}(\mathrm{SC})^{2}$, as per Lunstra et al. (1988).

\section{Blood collection for quantification of testosterone}

Blood samples for testosterone quantification were collected by jugular venipuncture (Vacutainer ${ }^{\circledR}$ ), followed by centrifugation at $1500 \mathrm{~g}$ for 10 minutes and storage of the serum in cryovials (Eppendorf®) at $-20^{\circ} \mathrm{C}$ for later radioimmunoassay (RIA) testosterone processing using commercial kits (Coat a Count ${ }^{\circledR}$, Siemens, Los Angeles, USA).

\section{Statistical data processing}

Analysis of variance was performed for the comparison of means related to related to testosterone and physical and testes biometry variables between the different data collection moments, followed by a comparison of means via Tukey's test at a significance level $\alpha=5 \%$, similar to the methods employed by Chacur al. $(2012,2013$, 2014). For an appropriate description of variables over the collection periods, descriptive analysis was performed to present the results in terms of mean values and standard deviations. 
For the determination of correlations between all variables in the present study, the Pearson correlation coefficient was determined - considering correlations when $\mathrm{p}$-values were smaller than 0.5 .

Regression analysis was employed for the generation of polynomial models for all variables, comprising studies of linear and quadratic curves in models having time (in months) as the independent variable. In all models, the most appropriate curve - the one with the coefficient of higher polynomial degree associated with an analysis with p-value smaller than 0.05 - was selected in an initial stage; should a quadratic curve satisfy the condition in the first stage, it would be selected.

To determine a relationship (polynomial model) between some correlated variables a regression analysis, analogous to the one mentioned above, was used.

To determine the degrees of similarity between the measured variables, a multivariate analysis was performed - specifically, cluster analysis, generating a Dendrogram with the objective of clustering variables with higher similarities. The analysis considered data measured on animals after the age of 12 months, since all variables were measured from this point onwards.

\section{Results}

For body weight, scrotal circumference (SC) and girth $(G)$, there were significant differences $(P$ $<0.05$ ) between the ages of 12,14 , and 16 months, with increasing values (Table 1 and Figure 1). At 10 months of age, all variables exhibited similar behaviors, with a significant increase observed between 12 to 16 months. The behavior emphasizes the importance of verifying the relationship (or correlation) between these variables, which can be seen in Table 2.

Table 1. Mean values and standard deviations for body weight (W), scrotal circumference (SC) and girth (G) measured every 56 days in male Brahman breed animals aged between 259 days ( $1^{\text {st }}$ collection) and 497 days $\left(6^{\text {th }}\right.$ collection), created extensively in collective grazing weight gaining performance tests, Uberaba-MG.

\begin{tabular}{ccccc}
\hline Collection & Age (months) & Weight $(\mathrm{kg})$ & $\mathrm{SC}(\mathrm{cm})$ & $\mathrm{G}(\mathrm{m})$ \\
\hline 1 & 8 & $239.71 \pm 33.94 \mathrm{C}$ & $\ldots .$. & $\ldots .$. \\
2 & 10 & $261.76 \pm 29.76 \mathrm{C}$ & $21.31 \pm 1.83 \mathrm{C}$ & $1.46 \pm 0.06 \mathrm{C}$ \\
3 & 12 & $252.38 \pm 30.16 \mathrm{C}$ & $22.11 \pm 2.14 \mathrm{C}$ & $1.48 \pm 0.06 \mathrm{C}$ \\
4 & 14 & $298.46 \pm 27.78 \mathrm{~B}$ & $23.96 \pm 2.55 \mathrm{~B}$ & $1.55 \pm 0.06 \mathrm{~B}$ \\
5 & 16 & $353.60 \pm 29.66 \mathrm{~A}$ & $26.76 \pm 2.58 \mathrm{~A}$ & $1.65 \pm 0.05 \mathrm{~A}$ \\
6 & 18 & $378.16 \pm 31.49 \mathrm{~A}$ & $27.77 \pm 2.77 \mathrm{~A}$ & $1.70 \pm 0.08 \mathrm{~A}$ \\
\hline
\end{tabular}

Legend: A, B, C - Capital letters in different columns differ among themselves $(\mathrm{P}<0.05)$.

The same table shows one single significant correlation between these variables, namely between SC and weight (0.85). Thus, a curve for the prediction of SCs as a function of weight can be generated, creating a prediction model to help producers and researchers determine $\mathrm{SC}$ as a function of weight
(Figure 2a). It is worth mentioning the correlation between the variables weight and Testosterone (ST), the highest correlation $(0.56)$ found for the latter variable, which similarly justified a ST prediction curve as a function of weight (Figure $2 b$ ). 
Figure 1. Polynomial models of body weight (W) (quadratic), scrotal circumference (SC) (linear) and girth $(\mathrm{G})$ (quadratic) as a function of animal age.
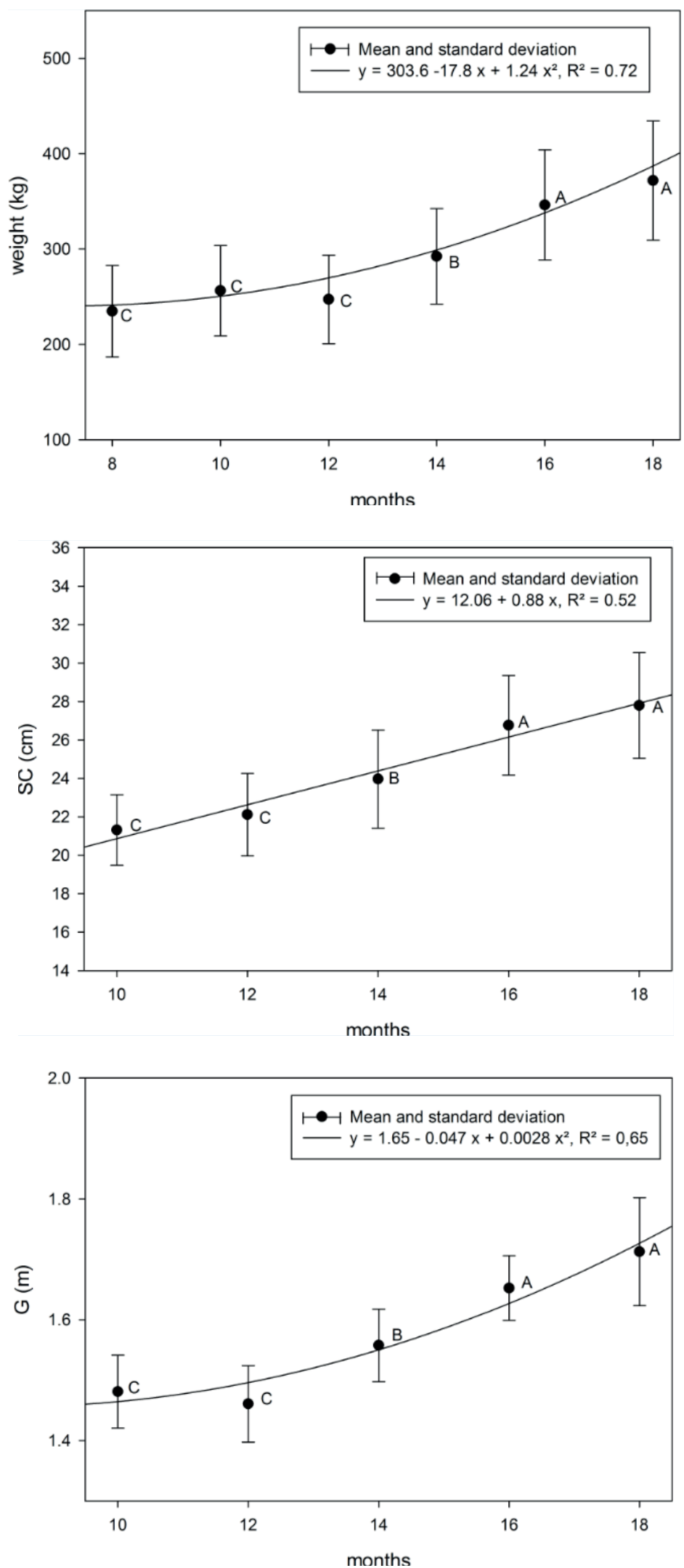
Table 2. Significant correlations $(\mathrm{P}<0.01)$ between the physical and testicular biometric characteristics measured every 56 days in male Brahman cattle aged between 259 days ( $1^{\text {st }}$ collection) and 497 days ( $6^{\text {th }}$ collection), raised extensively in collective grazing weight gaining performance tests, Uberaba-MG.

2012/2013.

\begin{tabular}{|c|c|c|c|c|c|c|c|c|c|c|c|c|}
\hline & SC & $\mathbf{G}$ & WH & BL & BMI & ADG & RTL & RTH & LTL & LTH & TV & ST \\
\hline Weight & 0.83 & - & - & - & 0.76 & 0.36 & 0.64 & 0.81 & 0.56 & 0.75 & 0.71 & 0.56 \\
\hline SC & & - & - & - & 0.65 & 0.50 & 0.79 & 0.91 & 0.75 & 0.90 & 0.91 & 0.41 \\
\hline TP & & & 1 & 1 & -0.46 & - & - & - & - & - & - & 0.34 \\
\hline WH & & & & 1 & -0.46 & - & - & - & - & - & - & 0.39 \\
\hline BL & & & & & -0.46 & - & - & - & - & - & - & 0.40 \\
\hline BMI & & & & & & 0.62 & 0.43 & 0.61 & 0.42 & 0.62 & 0.52 & 0.40 \\
\hline ADG & & & & & & & 0.54 & 0.65 & 0.45 & 0.56 & 0.57 & - \\
\hline RTL & & & & & & & & 0.74 & 0.85 & 0.70 & 0.89 & - \\
\hline RTH & & & & & & & & & 0.68 & 0.93 & 0.87 & 0.23 \\
\hline LTL & & & & & & & & & & 0.72 & 0.87 & - \\
\hline LTH & & & & & & & & & & & 0.87 & 0.21 \\
\hline TV & & & & & & & & & & & & 0.22 \\
\hline
\end{tabular}

Legend: variable pairs with a positive correlation coefficient tend to increase together; variable pairs with negative correlation coefficients, one variable tends to decrease as the other increases. For pairs with the "-" symbol, there is no relationship between the two variables, $\mathrm{P}<0.05$.

Figure 2. Linear Models of scrotal circumference (SC) and Testosterone (ST) as a function of weight.

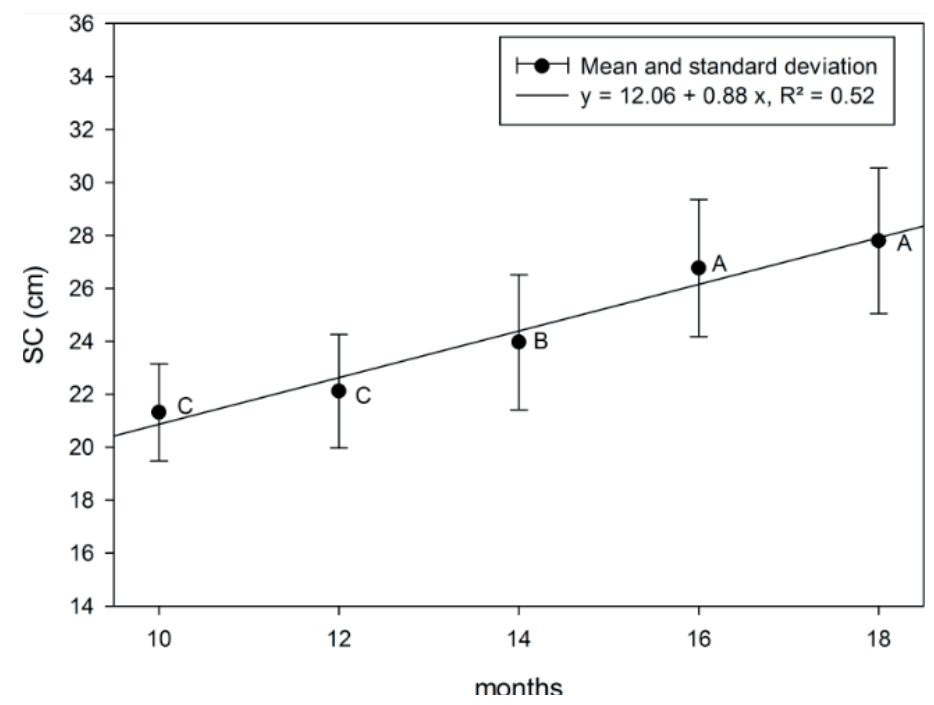




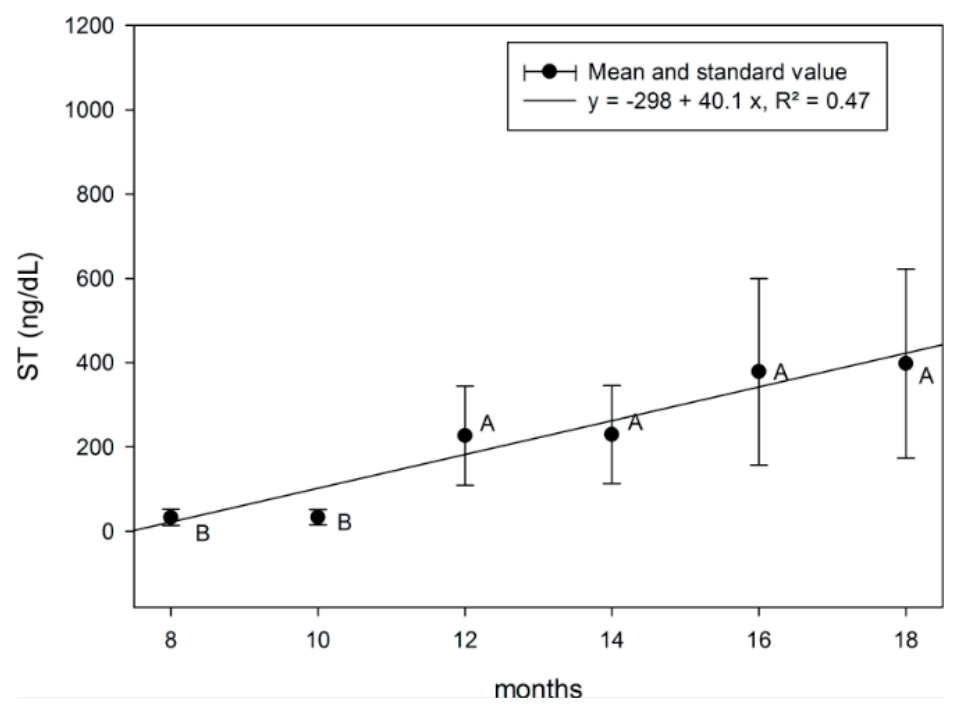

As the animals kept growing, several significant positive correlations between physical and testicular morphometry variables were expected. According to Table 2, there was a high correlation between testicular volume (TV) and body weight $(r=0.70 ; \mathrm{P}$ $<0.01)$; TV $x$ SC $(\mathrm{r}=0.90 ; \mathrm{P}<0.01)$, and TV $\times$ BMI $(\mathrm{r}=0.93 ; \mathrm{P}<0.01)$. Positive correlations $(\mathrm{P}<0.01)$ were also observed between SC and age $(\mathrm{r}=0.72)$, body weight $(\mathrm{r}=0.83)$, testicular length $(\mathrm{r}=0.74)$, and testicular height $(\mathrm{r}=0.89)$.

Positive correlations asserted the influence of testosterone on physical and testicular morphometric variables: ST x G $(r=0.38$; $\mathrm{P}<0.01)$; ST x WH $(\mathrm{r}=0.38 ; \mathrm{P}<0.01)$; ST xRTH $(\mathrm{r}=0.23$; P $<0.05)$; ST $x$ LTH $(\mathrm{r}=0.21 ; \mathrm{P}<0.01)$; and ST $\mathrm{x}$ TV $(\mathrm{r}=0.22 ; \mathrm{P}<0.008)$ (Table 2). Among the physical and testicular morphometric variables, the largest positive correlations with testosterone were found for girth and height at the withers.

For height at the withers (WH), body length (BL), and body mass index (BMI), the behavior is analogous to mean differences with animal age, with significant differences $(\mathrm{P}<0.05)$ between 14 and 16 months (Table 3 and Figure 3 ). It is worth noting that the only correlation with $\mathrm{SC}$ is given by the BMI variable ( $\mathrm{r}=0.76)$ (Table 2). This result is expected, since BMI is obtained directly from the bodyweight, and also by the similarity of these variables according to the Dendrogram of Figure 4. The correlation of the latter variable with SC is greater than that between BMI and SC, which does not justify the need to create a model for SC prediction at this point. 
Table 3. Mean values and standard deviations for height at the withers (WH), body length (BL), and body mass index (BMI) measured every 56 days in male Brahman cattle aged between 259 days ( $1^{\text {st }}$ collection $)$ and 497 days $\left(6^{\text {th }}\right.$ collection), raised extensively in collective grazing weight gaining performance tests, Uberaba-MG.

\begin{tabular}{ccccc}
\hline Collection & Age (months) & WH $(\mathrm{m})$ & BL $(\mathrm{m})$ & BMI $\left(\mathrm{kg} . \mathrm{m}^{-2}\right)$ \\
\hline 1 & 8 & $\ldots$. & $\ldots .$. & $\ldots .$. \\
2 & 10 & $1.16 \pm 0.03 \mathrm{~B}$ & $1.19 \pm 0.04 \mathrm{~B}$ & $193.15 \pm 16.74 \mathrm{~B}$ \\
3 & 12 & $1.17 \pm 0.03 \mathrm{~B}$ & $1.21 \pm 0.04 \mathrm{~B}$ & $181.55 \pm 16.80 \mathrm{~B}$ \\
4 & 14 & $1.18 \pm 0.03 \mathrm{~B}$ & $1.21 \pm 0.04 \mathrm{~B}$ & $212.05 \pm 15.60 \mathrm{~B}$ \\
5 & 16 & $1.24 \pm 0.04 \mathrm{~A}$ & $1.29 \pm 0.03 \mathrm{~A}$ & $227.90 \pm 17.05 \mathrm{~A}$ \\
6 & 18 & $1.26 \pm 0.03 \mathrm{~A}$ & $1.29 \pm 0.04 \mathrm{~A}$ & $236.87 \pm 18.02 \mathrm{~A}$ \\
\hline
\end{tabular}

Legend: A, B, C - Capital letters in different columns differ among themselves $(\mathrm{P}<0.05)$.

Figure 3. Polynomial (quadratic) models for height at the withers (WH), Body length (BL) and Body mass index (BMI) as a function of animal age.
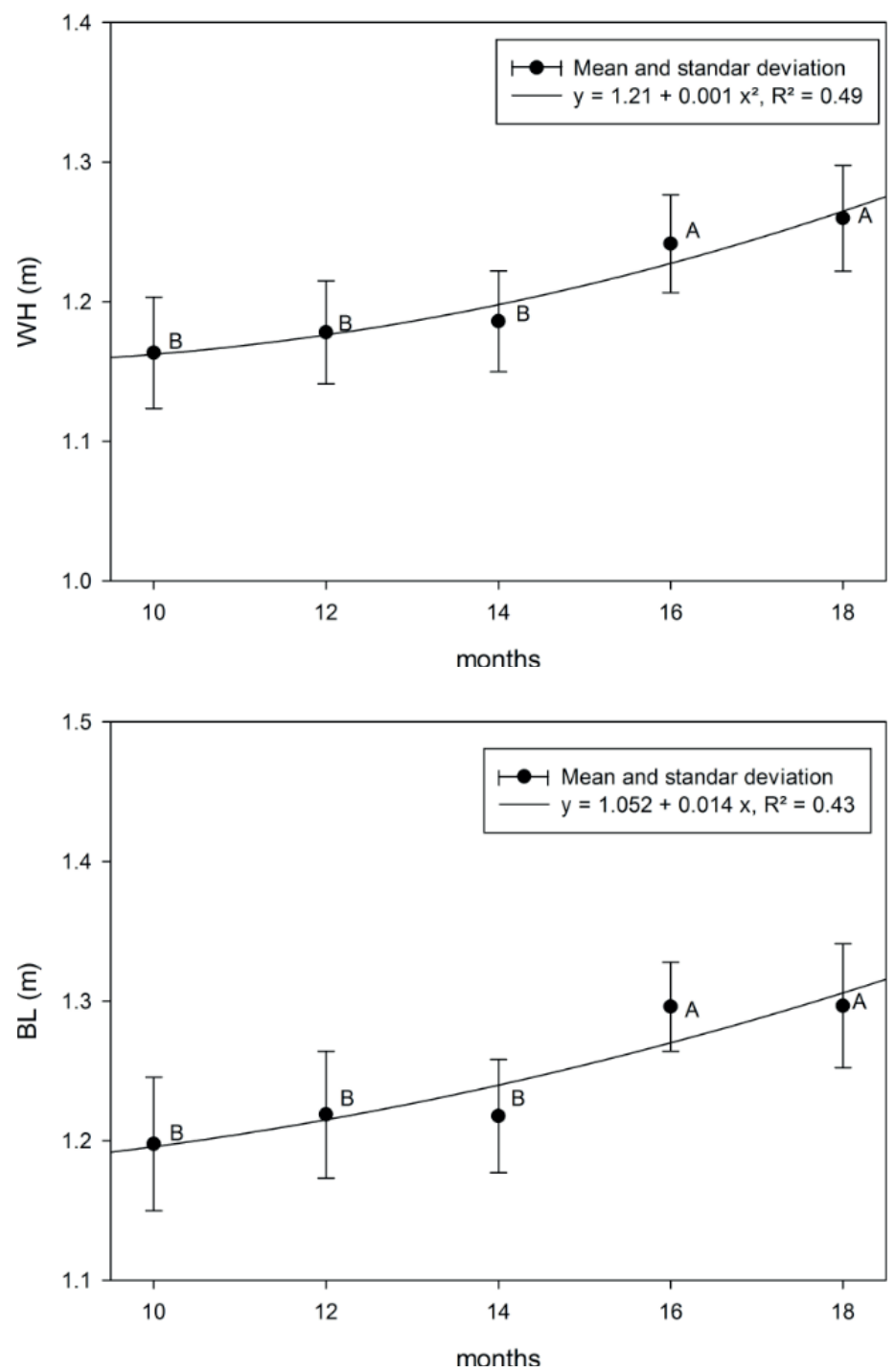


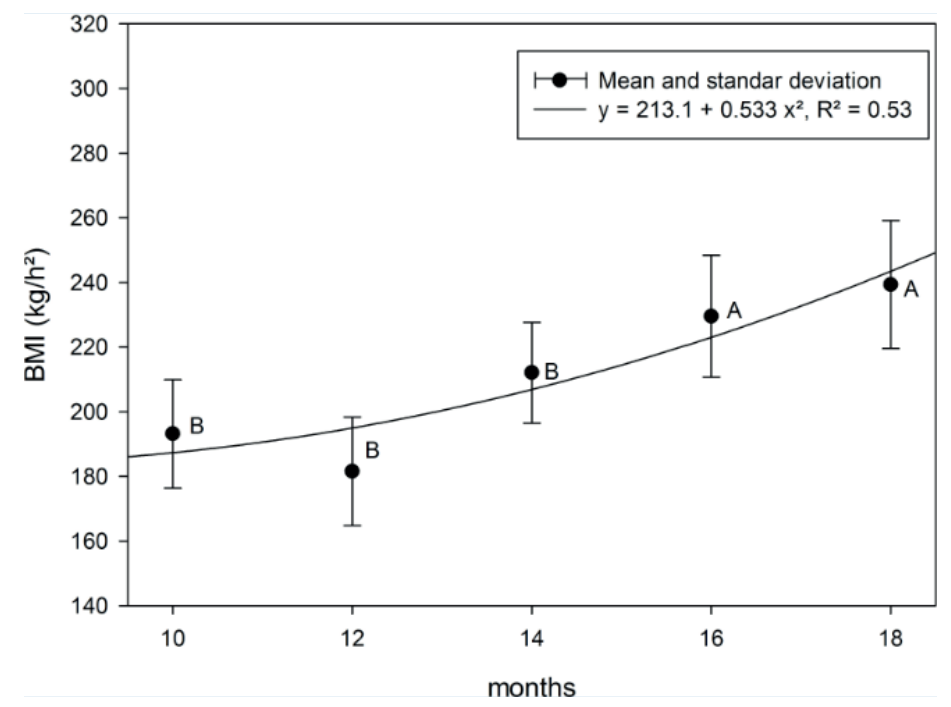

Figure 4. Dendrogram generated by multivariate analysis of variables between the body and testicular biometric characteristics in Brahman cattle males aged from 379 days (third collection) to 497 days (sixth collection).

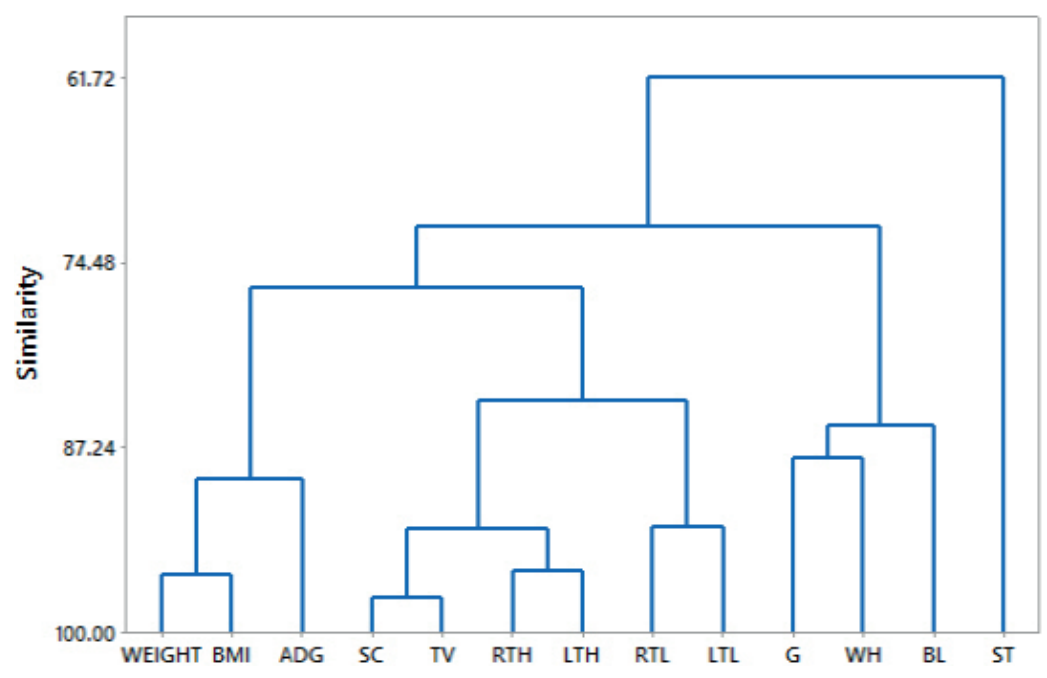

The analysis of the Dendrogram (Figure 3) emphasizes the similarity of the cluster of variables related to the weight (weight, BMI, ADG), with the group of variables related to the morphology of the reproductive tract (SC, TV, RTH, LTH, RTL, LTL) and the group of variables related to physical morphometry (G, WH, BL); the lack of similarity of Testosterone (ST) to any other variable is also noted. Thus, correlations between variables of different groups are of great interest as they reveal relationships that, unlike the correlation between BMI and weight, are not obvious.

Specifically, it is possible to relate the four groups. Multiple polynomial regression was employed to predict the level of testosterone (ST) using one (1) variable from each group, in search of the one with the highest correlation to ST. According to Table 2 , such variables and their correlations are weight 
(0.56), SC (0.41), and BL (0.40), thereby generating the polynomial:

$$
\begin{gathered}
S T=9236-21.8 x_{1}-271 x_{2}-9545 x_{3} \\
+0.01 x_{1}^{2}+0.6 x_{2}^{2}+952 x_{3}^{2}+0.46 x_{1} x_{2} \\
+18.8 x_{1} x_{3}+282 x_{2} x_{3}-0.61 x_{1} x_{2} x_{3}
\end{gathered}
$$

With $\mathrm{R}^{2}=0.23(\mathrm{P}<0.001)$, and and representing the variables WEIGHT, SC, and BL, respectively. Figure 5 shows the ST behavior upon variation of two (2) independent variables, with the third kept constant. It is thus possible to observe that in animals with high SC and low weight, or in animals with low SC and high weight, higher levels of testosterone were observed (Figure 5a). One can also observe that higher BL values correlate with higher testosterone levels (Figure 5b). The same figure shows that testosterone levels remain mostly unchanged with weight. Finally, it is worth noting that high BL values imply increased levels of testosterone (Figure 5c).

Figure 5. Surface contour maps generated by the multiple polynomial regression function at the clipping planes (a) Weight $=324.5$, (b) $\mathrm{SC}=25.3$, and (c) $\mathrm{BL}=1.26$

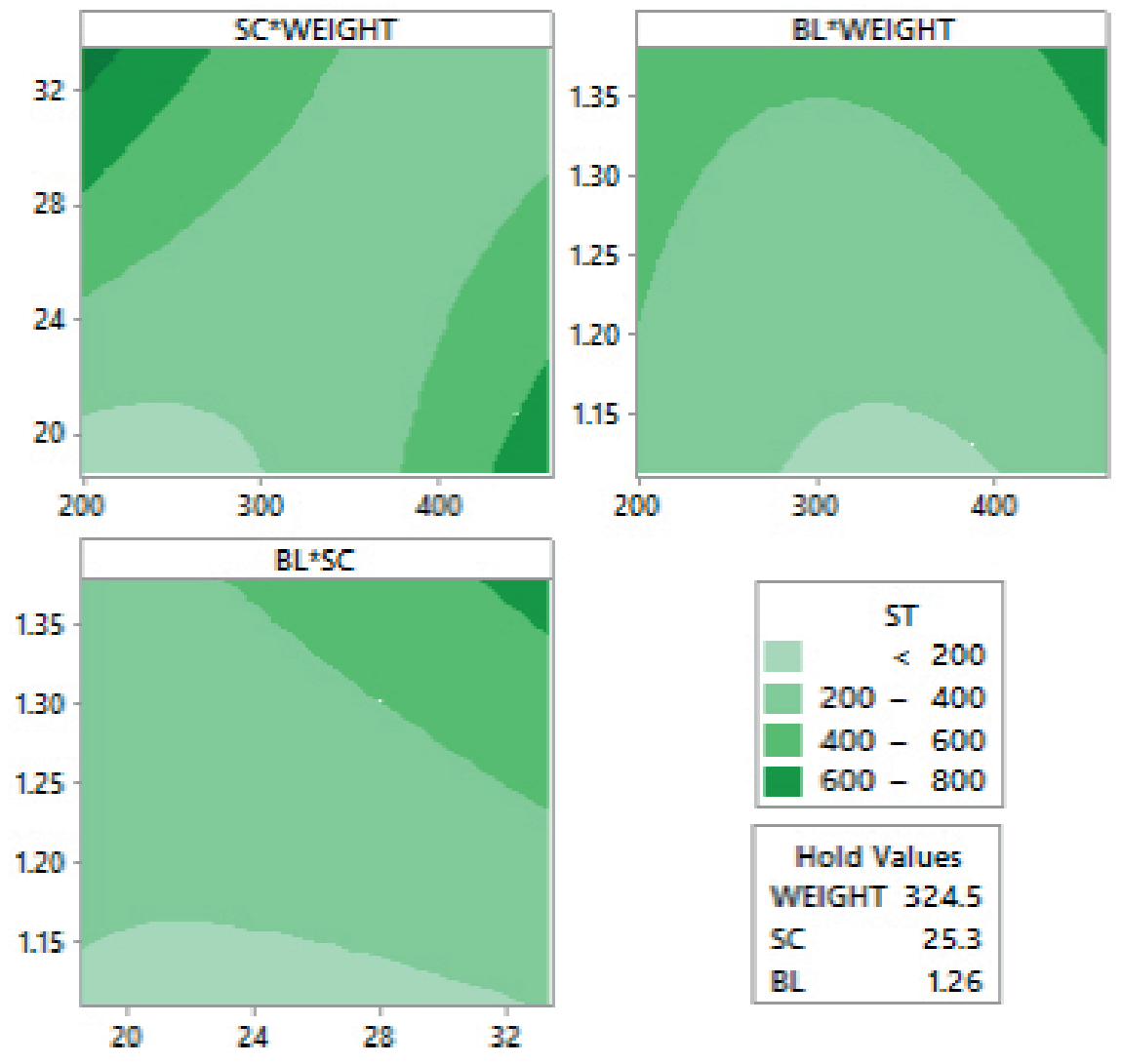

With respect to the height of the testes (craniocaudal axis), there were significant differences ( $\mathrm{P}$ $<0.05$ ) between 12,14 and 16 months of age. Testes

length (dorsal-ventral axis) differed $(\mathrm{P}<0.01)$ between 12 and 16 months (Table 4 and Figure 6). 
Table 4. Mean values and standard deviations for right testicular length (RTL), right testicular height (RTH), left testicular length (LTL) and left testicle height (LTH) measured every 56 days in male Brahman cattle aged between 259 days ( $1^{\text {st }}$ collection) and 497 days $\left(6^{\text {th }}\right.$ collection $)$, raised extensively in collective grazing weight gaining performance tests, Uberaba-MG.

\begin{tabular}{cccccc}
\hline Collection & Age (months). & RTL $(\mathrm{cm})$ & RTH $(\mathrm{cm})$ & LTL $(\mathrm{cm})$ & LTH $(\mathrm{cm})$ \\
\hline 1 & 8 & $\ldots$. & $\ldots \ldots$ & $\ldots .$. & $\ldots .$. \\
2 & 10 & $\ldots$. & $\ldots \ldots$ & $\ldots .$. & $\ldots .$. \\
3 & 12 & $7.79 \pm 1.03 \mathrm{~B}$ & $3.74 \pm 0.56 \mathrm{C}$ & $7.74 \pm 1.06 \mathrm{~B}$ & $3.90 \pm 0.49 \mathrm{C}$ \\
4 & 14 & $8.27 \pm 1.44 \mathrm{~B}$ & $4.60 \pm 0.64 \mathrm{~B}$ & $8.11 \pm 1.42 \mathrm{AB}$ & $4.57 \pm 0.64 \mathrm{~B}$ \\
5 & 16 & $9.15 \pm 1.37 \mathrm{~A}$ & $5.11 \pm 0.60 \mathrm{~A}$ & $8.84 \pm 1.21 \mathrm{~A}$ & $5.03 \pm 0.59 \mathrm{~A}$ \\
6 & 18 & $9.35 \pm 1.33 \mathrm{~A}$ & $5.44 \pm 0.68 \mathrm{~A}$ & $9.09 \pm 1.36 \mathrm{~A}$ & $5.29 \pm 0.71 \mathrm{~A}$ \\
\hline
\end{tabular}

Legend: A, B, C - Capital letters in different columns differ among themselves $(\mathrm{P}<0.05)$.

Figure 6. Polynomial models of the right testicular length (RTL) (linear), right testicular height (RTH) (quadratic), left testicle length (LTL) (quadratic) left testicular height (LTH) (quadratic) as a function of animal age.
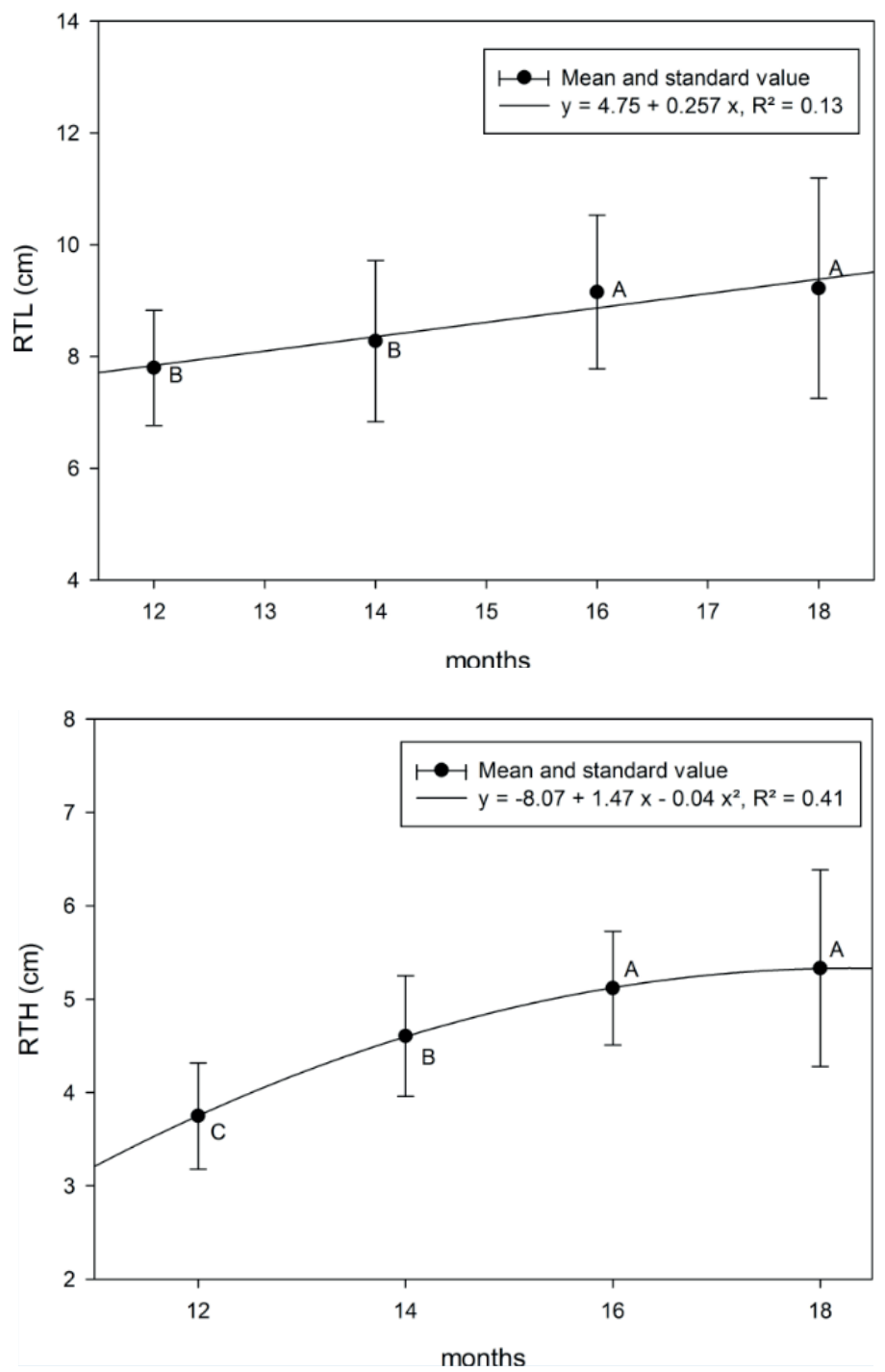

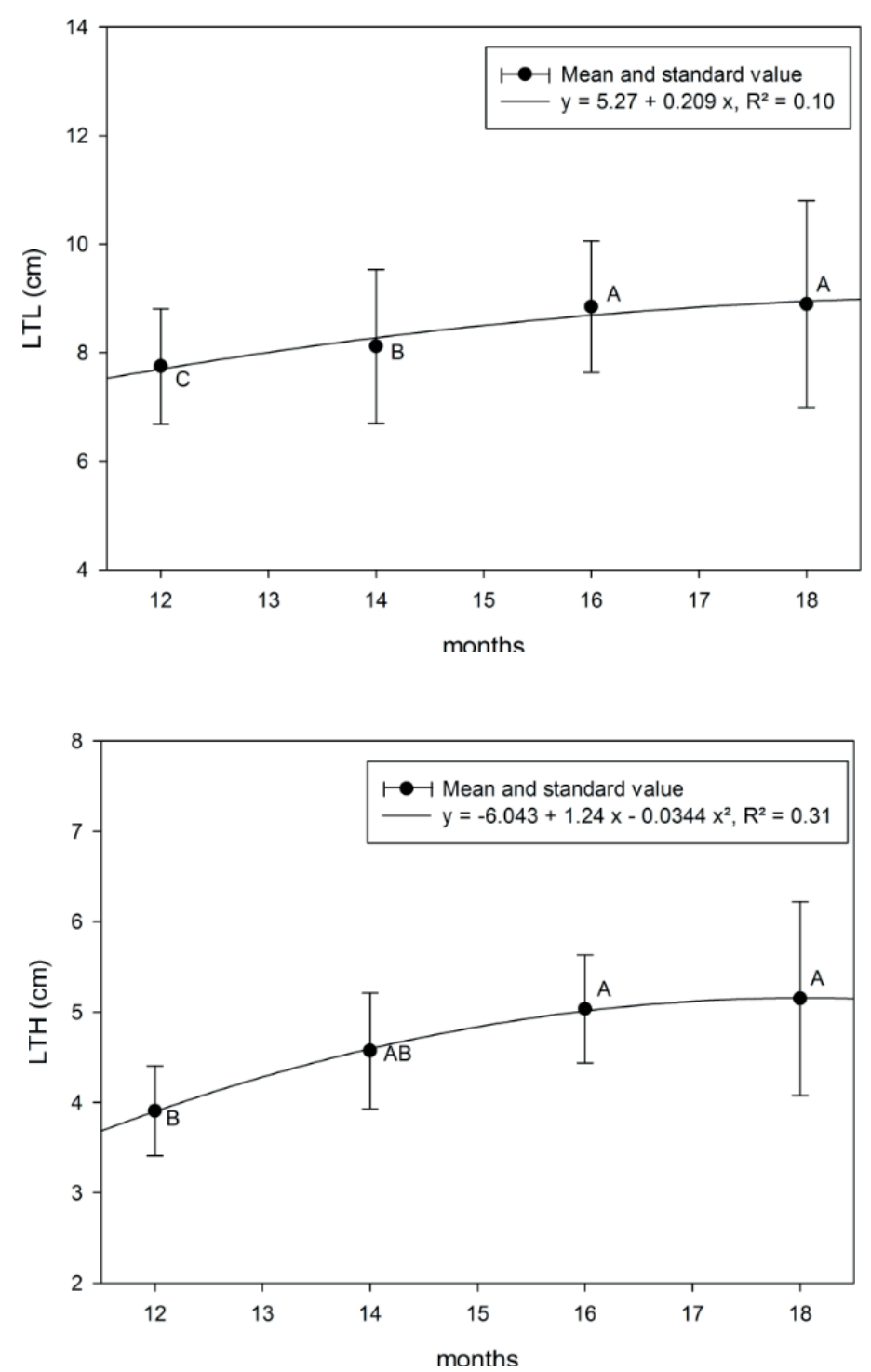

The average daily weight gain (ADG) increased 16 months. The serum testosterone concentration significantly between $8,10,12$ and 14 months of age differed $(\mathrm{P}<0.05)$ between 10 and 12 months (Table $(\mathrm{P}<0.05)$, but not between 14, 16 and 18 months of 5 and Figure 7$)$. age $(\mathrm{P}>0.05)$. TV differed $(\mathrm{P}<0.05)$ between 14 and 
Table 5. Averages and standard deviations for average daily gain (ADG), testicular volume (TV) and testosterone (ST) measured every 56 days in male Brahman cattle aged between 259 days ( $1^{\text {st }}$ collection) and 497 days ( $6^{\text {th }}$ collection), raised extensively in collective grazing weight gaining performance tests, Uberaba-MG.

\begin{tabular}{ccccc}
\hline Collection & Age (months) & ADG $(\mathrm{g} /$ day $)$ & TV $\left(\mathrm{cm}^{3}\right)$ & Testosterone $(\mathrm{ng} / \mathrm{dL})$ \\
\hline 1 & 8 & $0.79 \pm 0.10 \mathrm{~A}$ & $\ldots \ldots$ & $32.97 \pm 19.31 \mathrm{~B}$ \\
2 & 10 & $0.69 \pm 0.06 \mathrm{~B}$ & $\ldots .$. & $33.40 \pm 18.27 \mathrm{~B}$ \\
3 & 12 & $0.56 \pm 0.07 \mathrm{C}$ & $154.68 \pm 47.59 \mathrm{~B}$ & $226.80 \pm 117.60 \mathrm{~A}$ \\
4 & 14 & $0.69 \pm 0.05 \mathrm{~B}$ & $193.80 \pm 74.90 \mathrm{~B}$ & $229.40 \pm 116.40 \mathrm{~A}$ \\
5 & 16 & $0.73 \pm 0.04 \mathrm{AB}$ & $263.10 \pm 88.60 \mathrm{~A}$ & $378.80 \pm 221.40 \mathrm{~A}$ \\
6 & 18 & $0.69 \pm 0.07 \mathrm{~B}$ & $288.80 \pm 96.10 \mathrm{~A}$ & $398.00 \pm 224.50 \mathrm{~A}$ \\
\hline
\end{tabular}

Legend: A, B, C - Capital letters in different columns differ among themselves $(\mathrm{P}<0.05)$.

Figure 7. Polynomial models of the average daily gain (ADG), testicular volume (TV) and testosterone (ST) as a function of animal age.
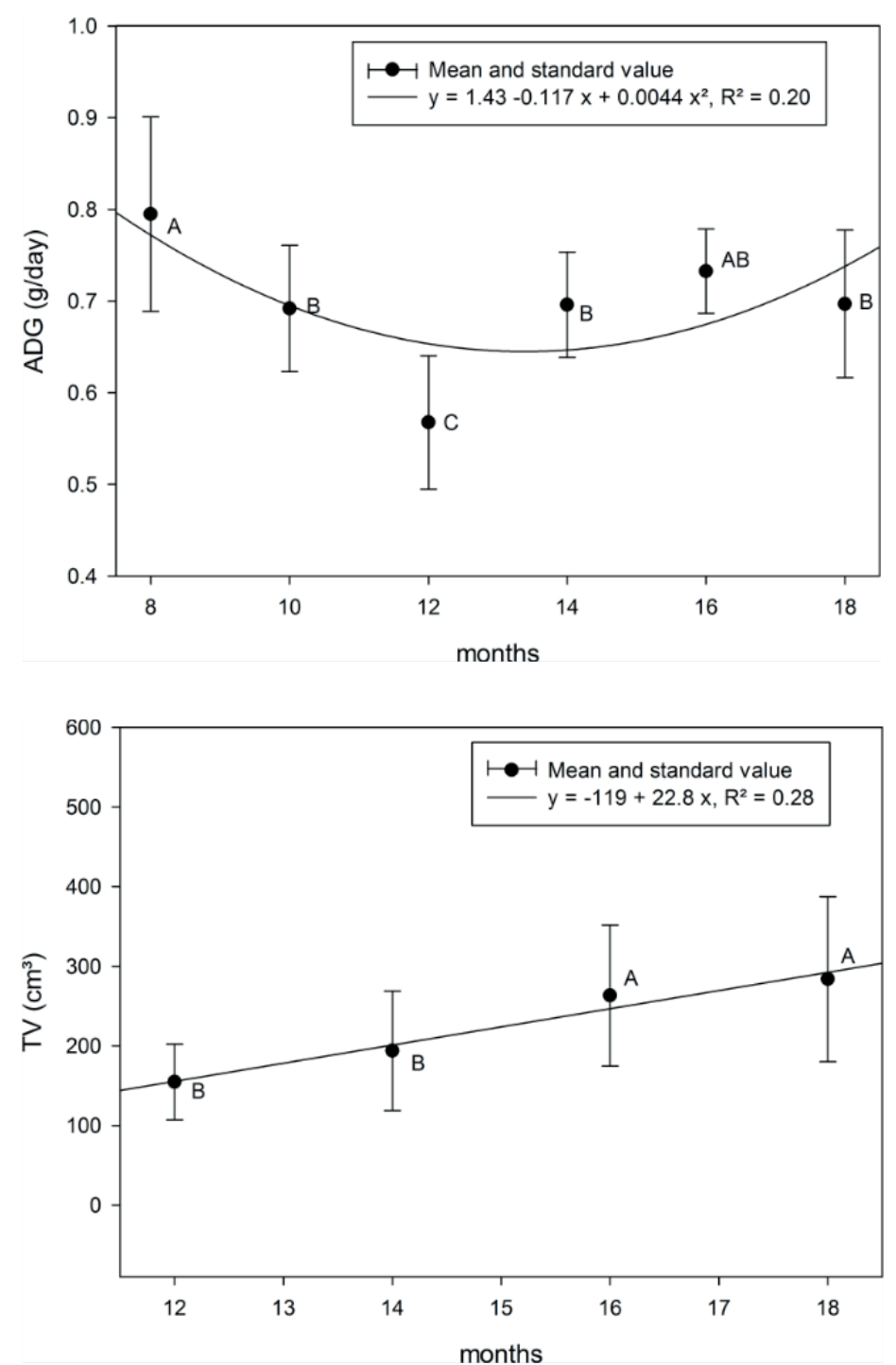


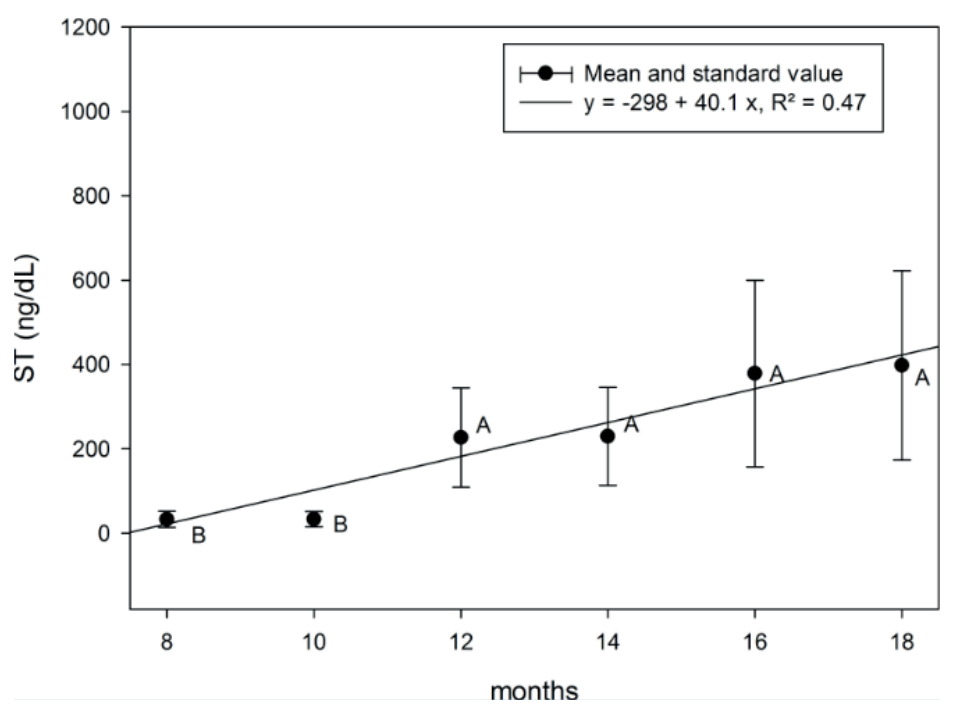

\section{Discussion}

Studies of body growth in zebu cattle focus mainly on body weight and ADG evaluations (LÔBO et al., 2006; PACHECO et al., 2008). Body morphometry, although subjected to fewer studies, is useful in the assessment of physical growth and development (PACHECO et al., 2008); physical development in bulls must be assessed by testicular volume increase (BERGMANN, 1999).

Assuming that the set of physical morphometry measurements opens more possibilities to evaluate body growth in young bulls, the present study measured data from different regions of the body of Brahman bulls. Body weight and girth $(\mathrm{G})$ differed $(\mathrm{P}<0.05)$ between 12, 14 and 16 months (Table 1) in Brahman bulls; these differences were only observed from 14 months of age onwards in Nellore males (FRENEAU et al., 2006). The body weight and girth of Brahman cattle at 12 and 14 months of age (Tab.1) were higher in Brahman males than in Nellore males (FRENEAU et al., 2006; UNANIAN et al., 2000) and in dual-use Guzerat zebus (PACHECO et al., 2008) in the same age groups.

The average body weight was numerically lower $(\mathrm{P}<0.05)$ at 12 months of age, compared to 10 months of age, probably due to the exclusive feeding on grazing: the quality of grass varies throughout the different seasons, and in the present study the dry season coincided with this age group, in agreement with Unanian et al. (2000) who evaluated Nellore in grazing weight gaining performance (WGP) tests. However, there was no difference $(\mathrm{P}>0.05)$ between 10 and 12 months of age for the SC and $\mathrm{G}$ variables. Sexual precocity is more related to body weight than to the chronological age of animals; thus, the analysis of several morphometric characteristics is important to guide the selection for genetic improvement purposes (CHACUR et al., 2010; REDDY et al., 2014; KUMAR et al., 2016). Sexual precocity was described in Nellore cattle aged between 500 and 580 days and between 620 and 740 days of age (BRITO et al., 2004). The different studies suggest that weight differences at similar ages in young Zebus may be related to the change in feed composition and distinct genetic lineages.

The scrotal circumference is the body morphometry variable that best estimates the puberty phase in Bos indicus males (BRITO et al., 2004). Mean SC values differed $(P<0.01)$ at 12 , 14 and 16 months of age (Table 1), similar to the report by Freneau et al. (2006) in similarly-aged Nellores. However, SC values were higher in the present study than in Brito et al. (2004), Freneau et al. (2006), and Neves et al. (2011). The significant 
increase of SC from 12 to 16 months in Brahman cattle is similar to that observed in Nellore cattle, probably because both are zebu breeds. On the other hand, the results of the present study revealed that significant SC increases occur at a later age than that reported by Boligon et al. (2011) in Nellore, who reported a significant increase from nine to 12 months of age. Also in Nellore, puberty occurred at a mean age of 526 days with a mean weight of $280 \mathrm{~kg}$ and mean scrotal circumference of $22 \mathrm{~cm}$ in young bulls classified as sexually precocious (BRITO et al., 2004). There is a wide variation in scrotal circumference in relation to the age of the Zebu bulls; in the present study, Brahman males with an average weight of $240 \mathrm{~kg}$ at 12 months of age reached a mean $\mathrm{SC}$ value of $22 \mathrm{~cm}$, suggesting satisfactory sexual precocity.

There was a high positive correlation between weight and $\mathrm{SC}(\mathrm{r}=0.83 ; \mathrm{P}<0.01)$ (Table 2), similar to that reported by Unanian et al. (2000), Valentim et al. (2002), Forni and Albuquerque (2004) and Pastore et al. (2008) in Nellore cattle; Mota et al. (2010) and Moura et al. (2002) in Brahman cattle; and Dias et al. (2009) in Guzerat cattle.

Apositive correlation $(\mathrm{r}=0.90 ; \mathrm{P}<0.01)$ was found for SC x TV (Tab.2), in agreement with Menegassi et al. (2011) for growing cattle, suggesting that SC is influenced by race, body condition score, age at puberty, and breeding system; the increase in testicular weight is proportional to the increase of body weight. Vásquez et al. (2003) recommended measuring the $\mathrm{SC}$ to follow testicular growth in Brahman cattle. Due to the elongated shape of testes in Brahman animals, the calculation of the testicular volume was efficient: although the animals may have slightly lower SC, the testicular volume is compensated by the length of the gonad.

The TV variable correlated with body weight $(\mathrm{r}=0.70 ; \mathrm{P}<0.01)$, justifying the importance of successive weightings at fixed time intervals in growing male animals. The present study also revealed a high positive correlation $(\mathrm{r}=0.93 ; \mathrm{P}$
$<0.01$ ) between TV and BMI, with the calculation of the latter being useful in monitoring animal growth, for identifying average height individuals with increased testicular volume, which can positively influence the concentration of spermatozoa in the ejaculate. This reasoning derived from the present study, which supports and complements the report by Menegassi et al. (2011) relating body weight and testicular weight; the present study supports the inclusion of the height at the withers variable to track the growth of Brahman males.

With the expansion of Fuzzy logic studies aimed at breeding animals (GABRIEL FILHO et al., 2011, 2016), one can mathematically model physical morphometric variable studies, attempting to predict how that variable behaves with time. Thus, the present study calculated the body mass index (BMI). In Brahman cattle, the BMI suffered a significant increase between 14 and 16 months. The variable is easy to obtain, as it requires only body weight and measurement of height at the withers as the animal is contained in the cattle crush. By using the BMI scoring nomenclature for the age of the animals in the present study, adopting the score published for adult zebu cattle with application of the fuzzy logic system according to Gabriel Filho et al. (2011, 2016), the mean BMI at ages 10 and 12 months (Tab.3) fall in the "very low BMI" category; the age of 14 months is classified as "low BMI"; and the ages of 16 and 18 months are classified as "high BMI". Brahman animals in the present study were young, with continuous increase in BMI due to the increase in height at the withers in conjunction with gains in body weight. Fifteen animals in the present study had a BMI greater than $242.8 \mathrm{~kg} . \mathrm{m}^{-2}$ at the age of 18 months (Table 3 ). The BMI was easily accessible, requiring only a scale and a graduated metric tape; it is recommended to calculate the BMI of young bulls, where 15 animals from a total of 40 showed a BMI score above average, suggesting a good weight-height ratio. The collection of BMI data for growing zebu bulls must be expanded, to allow the construction of an ideal physiological 
variation for each age group.

Body length (BL), like height at the withers and BMI, showed a significant increase between 14 and 16 months due to the rapid increase of those variables. Testes length and height showed differences $(\mathrm{P}<0.05)$ between 12, 14 and 16 months (Tab.4). These differences were obtained at younger ages than those reported by Freneau et al. (2006) in Nellore (15 to 17 months old).

Zebu physical development studies mainly evaluate body weight and average weight gain (LÔBO et al., 2006; PACHECO et al., 2008; OLMEDO et al., 2011). The average daily weight gain (ADG) of the present study was similar to that described by Olmedo et al. (2011) in Brahman cattle in the same age groups, and higher than the ADG reported in Nellore by Ribeiro et al. (2008). The present study showed differences $(\mathrm{P}<0.05)$ between 12, 14 and 16 months of age for body weight, and between 12 and 14 months for ADG. Body weight values were achieved at a younger age than those reported in Nellore by Moura et al. (2002), who exhibited a significant increase in body weight between 15 and 16 months of age. Although both the Brahman and Nellore breeds are zebu breeds, the difference may stem from the different geographical locations of the studies.

Testicular volume was described as a suitable variable for the evaluation of post-pubertal Bos indicus males (BRITO et al., 2004). Measurements of the length, width and height of the testes axes are useful for evaluating testicular symmetry and calculating testes volume (UNANIAN et al., 2000; RUEDIGER et al, 2016). At 12 and 18 months of age, the length, width and volume of testes were higher than the values reported in Nellore cattle by Unanian et al. (2000) at the same age groups. The TV differed $(\mathrm{P}<0.05)$ between 14 and 16 months (Tab.5). This difference was obtained later than in the studies by Forni and Albuquerque (2004) in Nellore, who described larger testicular development between 10 and 16 months of age, with a significant development between 10 and 11 months, and Moura et al. (2002) who observed a greater variation of the $\mathrm{SC}$ from 10 months of age. Since the SC is used in the calculation of the TV, the former influences testicular volumetry; thus, Unanian et al. (2000) suggested that in Zebus, who generally exhibit elongated testes, TV and SC should be adopted simultaneously to evaluate growth.

The rapid body development and acceleration of weight gain in the puberty of male beef breed cattle is associated with the increase in testosterone production (REDDY et al., 2014). Zebu breeds exhibit greater adaptability to the tropical climate, with a lower relative testosterone decrease in the summer compared to European breed bulls (QUEZADA-CASASOLA et al., 2016).

The serum testosterone concentration differed ( $\mathrm{P}<0.05$ ) between 10 and 12 months (Table 5), preceding a significant increase in morphological variables. At 12 months of age, the serum testosterone concentration in Brahman males was similar to that found in Nellore cattle aged 31 and 35 months by Ruediger et al. (2016), and in crossbred Holstein x Thaparkar males between 9 and 12 months of age by Kumar et al. (2016). In the present study, Brahman males produced similar levels of testosterone at younger ages than Zebus (RUEDIGER et al., 2016), and in the same age group as crossbred cattle (KUMAR et al., 2016), revealing sexual precocity.

High correlation $(\mathrm{r}=0.74)$ between $\mathrm{SC}$ and ST was observed, highlighting the hormonal influence on the development of testes. In agreement with Bergmann (1999) and Moura et al. (2002), the elevation of testosterone occurs prior to the rapid growth of the testes. Testicular development occurs slowly before the significant increase of the testosterone; gonad growth peaks during puberty, followed once more by slow growth, indicative of sexual maturity. In the present study, the high positive correlation between the concentration of testosterone and scrotal circumference (SC) renders 
measurement of the latter a good indicator of puberty, confirming reports by Brito et al. (2004), Quezada-Casasola et al. (2016), and Reddy et al. (2014).

In growing Brahman males, the evaluated morphometric variables were useful to follow the physical development. From 12 to 14 months, body weight, SC and girth increased rapidly, while the other variables rose significantly at 14 months of age.

Due to the growth of the animals, high positive correlations were found between physical and testicular morphometric variables. There was a correlation between age and weight $(\mathrm{r}=0.80 ; \mathrm{P}$ $<0.01$ ), similar to that described in Brahman cattle (VÁSQUEZ et al., 2003). At the ages of 16 and 18 months, SC and body weight values were similar to and higher than those reported in Nellore by Lopes et al. (2009), respectively.

In view of the results presented herein, the present work contributes with mean values and significant correlations on body and reproductive tract morphometry variables, which are useful in practical use and in the selection of young bulls bred in extensive management feeding on grass and mineral mix. Regarding puberty, it is clear that the increase in serum testosterone occurs to prepare the reproductive tract for rapid anatomical development.

\section{Conclusions}

A rapid increase in serum testosterone concentration occurred between 12 and 14 months of age. There is rapid anatomical physical and testicular growth after a significant increase in testosterone. The elevation of testosterone serves as an indirect indicator that the acceleration of physical and testicular growth is approaching. It is recommended to calculate the BMI and TV to follow the growth of cattle, due to the high correlation between these variables.

\section{Acknowledgements}

The National Council for Scientific and Technological Development (CNPq) and the Brazilian Association of Zebu Breeders (ABCZ).

\section{References}

BERGMANN, J. A. G. Seleção de zebuínos para precocidade sexual. In: SIMPÓSIO DE PRODUÇÃO DE GADO DE CORTE, 1., 1999, Belo Horizonte. Anais... Belo Horizonte: UFMG, 1999. p. 51-54.

BOLIGON, A. A.; BALDI, F.; ALBUQUERQUE, L. G. Genetic parameters and relationship between growth traits and scrotal circumference measured at different ages in Nellore cattle. Geneitcs and Molecular Biology, Ribeirão Preto, v. 34, n. 2, p. 225-230, 2011.

BRITO, L. F. C.; SILVA, A. E. D. F.; UNANIAN, M. M.; DODE, M. A. N.; BARBOSA, R. T.; KASTELIC, J. P. Sexual development and early- and late-maturing Bos indicus and Bos indicus $x$ Bos taurus crossbred bulls in Brazil. Theriogenology, New York, v. 62, n. 7, p. 11981217, 2004.

CHACUR, M. G. M.; AURÉlIO, P. T. F.; OBA, E.; LAPOSY, C. B.; SCALON, O. J.; INAGUE, L.; KRONKA, S. N. Influência de um nutracêutico no sêmen, testosterona, cortisol, eritrograma e peso corpóreo de touros jovens (Bos taurus indicus). Semina: Ciências Agrárias, Londrina, v. 31, n. 2, p. 531-542, 2010.

CHACUR, M. G. M.; MARTINS, E. A. F.; SILVA, A. A.; GUABERTO, L. M.; GABRIEL FILHO, L. R. A.; SANCHES, O. C.; OBA, E. Morfometria corpórea, características do sêmen, proteínas seminais e testosterona em cervos Cervus unicolor, em cativeiro. Arquivo Brasileiro de Medicina Veterinária e Zootecnia, Belo Horizonte, v. 66, n. 5, p. 1392-1400, 2014.

CHACUR, M. G. M.; MIZUSAKI, K. T.; GABRIEL FILHO, L. R. A.; OBA, E.; RAMOS, A. A. Seasonal effects on semen and testosterone in Zebu and Taurine Bulls. Acta Scientiae Veterinariae, Porto Alegre, v. 41, n. 1110, p. 1-5, 2013.

CHACUR, M. G. M.; MIZUSAKI, K. T.; SANTOS, F. H.; CESARE, A. G.; GABRIEL FILHO, L. R. A.; OBA, E.; RAMOS, A. A. Influência da estação do ano nas características do sêmen e na concentração de hormônios em touros Nelore e Simental. Arquivo Brasileiro de Medicina Veterinária e Zootecnia, Belo Horizonte, v. 64, n. 3, p. 540-546, 2012. 
CHENOWETH, J. P.; CHASE JUNIOR, C. C.; THATCHER, M. J. D.; WILCOX, C. J.; LARSEN, R. E. Breed and other effects on reproductive traits and breeding soundness categorization in young beef bulls in Florida. Theriogenology, New York, v. 46, n. 7, p. 11591170, 1996.

DIAS, J.; ANDRADE, V.; EMERICK, L.; MARTINS, J. A.; VALE FILHO, V. R.; SILVA, M. A. Teste da libido em touros jovens Guzerá e suas associações com características reprodutivas e níveis séricos de testosterona. Archives of Veterinary Science, América do Norte, v. 14, n. 4, p. 204-213, 2009.

FORNI, S.; ALBUQUERQUE, L. G. Avaliação das características biométricas de testículos de bovinos Nelore. In: SIMPÓSIO DA SOCIEDADE BRASILEIRA DE MELHORAMENTO ANIMAL, 5., 2004, Pirassununga. Anais... Pirassununga: Editora da Sociedade Brasileira de Melhoramento Animal, 2004. p. 1-3.

FRENEAU, G. E.; VALE FILHO, V. R.; MARQUES JUNIOR, A. P.; MARIA, W. S. Puberdade em touros Nelore criados em pasto no Brasil: características corporais, testiculares e seminais e de índice de capacidade andrológica por pontos. Arquivo Brasileiro de Medicina Veterinária e Zootecnia, Belo Horizonte, v. 58, n. 6, p. 1107-1115, 2006.

GABRIEL FILHO, L. R. A.; CREMASCO, C. P.; PUTTI, F. F.; CHACUR, M. G. M. Application of fuzzy logic for the evaluation of livestock slaughtering. Engenharia Agrícola, Jaboticabal, v. 31, n. 4, p. 813-825, 2011.

GABRIEL FILHO, L. R. A.; PUTTI, F. F.; CREMASCO, C. P.; BORDIN, D.; CHACUR, M. G. M.; GABRIEL, L. R. A. Software to assess beef cattle body mass through the fuzzy body mass index. Engenharia Agrícola, Jaboticabal, v. 36, n. 1, p. 179-193, 2016.

JOSAHKIAN, L. A.; MACHADO, C. H. C.; KOURY FILHO, W. Programa de melhoramento genético das raças zebuínas. Uberaba: ABCZ, 2003. 96 p.

KUMAR, B.; PANDITA, S.; PRAKASH, B. S.; MALLICK, S.; MILI, B. Responsiveness of prepubertal crossbred bull calves to exogenous GnRH and its impacts on reproductive hormones under on tropical conditions. Springer Plus, London, v. 8, n. 288, p. 288-292, 2016.

LÔBO, R. N. B.; VILLELA, L. C. V.; LOBO, A. M. B. O.; PASSOS, J. R. S.; OLIVEIRA, A. A. Parâmetros genéticos de características estimadas da curva de crescimento de ovinos da raça Santa Inês. Revista Brasileira de Zootecnia, Piracicaba, v. 35, n. 3, p. 10121019, 2006. Suplemento.
LOPES, J. S.; RORATO, P. R. N.; WEBER, T.; COMIN, J. G.; ARAÚJO, R. O. Fatores de correção para perímetro escrotal ao sobreano para tourinhos mestiços Aberdeen Angus $\mathrm{x}$ Nelore. Arquivo Brasileiro de Medicina Veterinária e Zootecnia, Belo Horizonte, v. 61, n. 2, p. 413-419, 2009.

LUNSTRA, D. D.; FORD, J. J.; ECHTERNKAMP, S. E. Puberty in beef bulls: hormone concentrations, growth, testicular development, sperm production and sexual aggressiveness in bulls of different breeds. Journal of Animal Science, New York, v. 46, n. 4, p. 1054-1062, 1978.

LUNSTRA, D. D.; GREGORY, K. E.; CUNDIFF, L. V. Heritability estimates and adjustment factors for effects of bull age and age of dam on yearling testicular size in breeds of beef bulls. Theriogenology, Philadelphia, v. 30, n. 1, p. 127-136, 1988.

MENEGASSI, S. R. O.; BARCELLOS, J. O. J.; PERIPOLLI, V.; PEREIRA, P. R. R. X.; BORGES, J. B. S.; LAMPERT, V. N. Measurement of scrotal circumference in beef bulls in Rio Grande do Sul. Arquivo Brasileiro de Medicina Veterinária e Zootecnia, Belo Horizonte, v. 63, n. 1, p. 87-93, 2011.

MOTA, M. F.; SOUZA, J. C.; MACHADO, C. H. C.; PINTO NETO, A.; FREITAS, J. A.; CEZARO, F. R. Evolução Fenotípica de características produtivas e reprodutivas avaliada pela biometria corporal de machos da Raça Brahman. In: CONGRESSO MUNDIAL DA RAÇA BRAHMAN, 15., 2010, Uberaba. Anais... Uberaba: ABCZ, 2010. p. 1-5.

MOURA, A. A. A.; RODRIGUES, G. C.; MARTINS FILHO, R. Desenvolvimento ponderal e testicular, concentrações periféricas de testosterona e características de abate em touros da raça Nelore. Revista Brasileira de Zootecnia, Viçosa, MG, v. 31, n. 2, p. 934-943, 2002. Suplemento.

NEVES, A. L. A.; DELREI, A. J.; SANTOS, M. P. Crescimento testicular de touros da raça Nelore. Livestock Research for Rural Development, Cali, v. 23, n. 4, 2011. Disponível em: <http://www.lrrd.org/lrrd23/4/ neve23093.htm>. Acesso em: 05 jun. 2017.

OLMEDO, D. O.; BARCELLOS, J. O. J.; CANELLAS, L. C.; VELHO, M. M. S.; PANIAGUA, P.; HORITÁ, I.; TAROUCO, J. U. Desempenho e características da carcaça de novilhos terminados em pastejo rotacionado ou em confinamento. Arquivo Brasileiro de Medicina Veterinária e Zootecnia, Belo Horizonte, v. 63, n. 2, p. 348355, 2011.

PACHECO, A.; QUIRINO, C.; PINHEIRO, O.; ALMEIDA, J. V. C. Medidas morfométricas de touros 
jovens e adultos da raça Guzerá. Revista Brasileira de Saúde e Produção Animal, Salvador, v. 9, n. 3, p. 426435, 2008.

PASTORE, A. A.; TONIOLlO, G. H.; LÔBO, R. B.; FERNANDES, M. B.; VOZZI, P. A.; VILA, R. A.; GALERANI, M. A. V.; ELIAS, E. P.; CARDILLI, D.

J. Características biométricas, testiculares, seminais e parâmetros genéticos de touros pertencentes ao programa de melhoramento genético da raça Nelore. $A R S$ Veterinária, Jaboticabal, v. 24, n. 2, p. 134-141, 2008.

QUEZADA-CASASOLA, A.; MARTÍNEZARMENDÁLIZ, K. E.; CARRERA-CHÁVEZ, J. M.; PÉREZ-EGUÍA, E.; RODRÍGUEZ-ALARCÓN, C. A.; AVENDAÑO-REYES, L. Effect of season on scrotal circumference, semen characteristics and testosterone serum concentration in Mexican Corriente and other beef breed bulls. Animal Reproduction, Belo Horizonte, v. 13, n. 4, p. 787-794, 2016.

REDDY, V. B.; SIVAKUMAR, A. S.; JEONG, D. W.; WOO, Y. B.; PARK, S. J.; LEE, S. Y.; BYUN, J. W.; KIM, C. H.; CHO, S. Y.; HWANG, I. Beef quality traits of heifer in comparison with steer, bull and cow at various feeding envinronments. Animal Science Journal, Tokyo, v. 86, n. 1, p. 1-16, 2014.

RIBEIRO, E. L. A.; HERNANDEZ, J. A.; ZANELLA, E. L.; MIZUBUTI, I. Y.; SILVA, L. D. F.; REEVES, J. J. Desempenho e características de carcaça de bovinos de diferentes grupos genéticos. Revista Brasileira de Zootecnia, Viçosa, MG, v. 37, n. 9, p. 1669-1673, 2008.

RUEDIGER, F. R.; CHACUR, M. G. M.; ALVES, F. C. P. E.; OBA, E.; RAMOS, A. A. Digital infrared thermography of the scrotum, semen quality, serum testosterone levels in Nellore bulls (Bos taurus indicus) and their correlation with climatic factors. Semina: Ciências Agrárias, Londrina, v. 37, n. 1, p. 221-232, 2016.

UNANIAN, M. M.; SILVA, A. E. D. F.; MCMANUS, C.; CARDOSO, E. P. Características biométricas testiculares para avaliação de touros zebuínos da raça Nelore. Revista Brasileira de Zootecnia, Viçosa, MG, v. 29, n. 1, p. 136144, 2000.

VALE FILHO, V. R.; BERGMANN, J. A. G.; ANDRADE, V. J.; QUIRINO, C. R.; REIS, S. R.; MENDONÇA, R. M. A. Andrologic characterization of Nelore bulls selected for the first breed season. Revista Brasileira de Reprodução Animal, Belo Horizonte, v. 21, n. 2, p. 42-44, 1997.

VALENTIM, R.; ARRUDA, R. P.; BARNABE, R. C.; ALENCAR, M. M. Biometria testicular de touros Nelore (Bos taurus indicus) e touros cruzados Nelore-europeu (Bos taurus indicus x Bos taurus taurus) aos 20 e 24 meses de idade. Brazilian Journal of Veterinary Research and Animal Science, São Paulo, v. 39, n. 3, p. 113-120, 2002.

VÁSQUEZ, L.; VERA, O; ARANGO, J. Testicular growth and semen quality in peripuberal Brahman bulls. Livestock Research for Rural Development, Cali, v. 15, n. 10, 2003. Available at: <http://www.lrrd.org/lrrd15/10/ vasqcit.htm>. Accessed at: 5 jun. 2017.

WOLF, F. R.; ALMQUIST, J. O.; HALE, E. B. Prepuberal behaviour and puberal characteristics of beef bulls on high nutrient allowance. Journal of Animal Science, New York, v. 24, n. 3, p. 761-765, 1965. 
